\title{
KUALITAS FISIKOKIMIA DAN MIKROBIA YOGHURT SINBIOTIK YANG DIBERI PATI TERMODIFIKASI UMBI UWI UNGU (Dioscorea alata) DENGAN LEVEL BERBEDA
}

\author{
Agnes C. Korengkeng, A. Yelnetty, Rahmawati Hadju, M. Tamasoleng
}

Fakultas Peternakan Universitas Sam Ratulangi Manado, 95115

\begin{abstract}
ABSTRAK
Penelitian ini bertujuan untuk mengetahui penambahan level pati termodifikasi umbi uwi ungu (Dioscorea alata) terhadap sineresis, $\mathrm{pH}$ dan total bakteri asam laktat (BAL) yoghurt sinbiotik. Penelitian ini menggunakan rancangan acak lengkap (RAL) dengan 6 perlakuan sebagai berikut $\mathrm{PO}=$ yoghurt tanpa pati termodifikasi umbi uwi ungu, P1 $=$ yoghurt $+0,1 \%$ pati termodifikasi umbi uwi ungu, $\mathrm{P} 2=$ yoghurt $+0,2 \%$ pati termodifikasi umbi uwi ungu, P3 = yoghurt $+0,3 \%$ pati termodifikasi umbi uwi ungu, $\mathrm{P} 4=$ yoghurt $+0,4 \%$ pati termodifikasi umbi uwi ungu dan P5 = yoghurt $+0,5 \%$ pati termodifikasi umbi uwi ungu dengan 3 ulangan. Variabel yang diamati yaitu sineresis, nilai $\mathrm{pH}$, total bakteri asam laktat (BAL). Data yang diperoleh dianalis menggunakan ANOVA, dan perbedaan antara perlakuan dilanjutkan dengan uji $\mathrm{F}$ or Tukey's test. Hasil penelitian menunjukan bahwa pemberian pati termodifikasi umbi uwi ungu dengan level berbeda memberikan pengaruh sangat nyata $(\mathrm{P}<0,01)$ terhadap nilai $\mathrm{pH}$ dan total BAL yoghurt sinbiotik, tetapi tidak pada nilai sineresis yoghurt sinbiotik. Akan tetapi nilai sineresis yoghurt sinbiotik cenderung menurun seiring dengan meningkatnya level pati termodifikasi ubi ungu. Range nilai $\mathrm{pH}$ pada yoghurt yang diberi pati termodifikasi adalah 5,0 - 5,4 dan nilai $\mathrm{pH}$ terendah 5,0 didapat pada pemberian $0,3 \%$ pati termodifikasi,
\end{abstract}

*Kosepondensi (corresponding author)

Email: ayelnetty@unsrat.ac.id sedangkan range total BAL yoghurt yang diberi pati termodifikasi adalah $\log { }^{10-7} 8,65$ $-\log { }^{10-7} 8,87$ dan nilai total BAL tertinggi $\log ^{10-7} 8,87$ didapat pada pemberian $0,2 \%$ pati termodifikasi. Disimpulkan pada penelitian ini bahwa kualitas terbaik yoghurt sinbiotik adalah pada yoghurt dengan penambahan pati termodifikasi umbi uwi ungu $0,3 \%$.

Kata Kunci : Yogurt Sinbiotik, Pati Termodifikasi Umbi Uwi Ungu, Sineresis, nilai $\mathrm{pH}$, Total BAL.

\section{ABSTRACT}

THE PHYSICOCHEMICAL AND MICROBIAL QUALITY OF SINBIOTIC YOGHURT GIVEN DIFFERENT LEVEL OF MODIFIED STARCH OF PURPLE UWI BULB (Dioscorea alata). An experiment was done in order to determine the level of modified starch of purple uwi bulb (Dioscorea alata) which best for syneresis, $\mathrm{pH}$ and total lactic acid bacteria of synbiotic yoghurt. Completely Randomized Design (CRD) was used in this experiment with 6 treatments as follows $\mathrm{P} 0=$ yoghurt without modified starch purple uwi bulb, P1 = yoghurt $+0,1 \%$ modified starch purple uwi bulb, $\mathrm{P} 2=$ yoghurt $+0,2 \%$ modified starch purple uwi bulb, P3 = yoghurt $+0,3 \%$ modified starch purple uwi bulb, P4 = yoghurt $+0,4 \%$ modified starch purple uwi bulb dan P5 = yoghurt $+0,5$ modified starch purple uwi bulb; and three repetitions each treatment. Measurements taken were syneresis, $\mathrm{pH}$ value, total of acid lactate bacteria. Data obtained were analyzed 
using ANOVA and Tuckey's test was used to inspect treatment differences among group means. It found in this research that application of modified starch of purple uwi bulb in symbiotic yoghurt gave a significant effect $(\mathrm{P}<0,01)$ on $\mathrm{pH}$ value and total lactic acid bacteria but not on syneresis. However, the syneresis values tendency decreased as the level of modified starch of purple uwi bulb increased. The $\mathrm{pH}$ of symbiotic yoghurts given modified starch were ranged between $5.0-5.4$ and the lowest $\mathrm{pH}$ was found in yoghurt with $0.3 \%$ modified starch added, meanwhile the total lactic acid bacteria of symbiotic yoghurts given modified starch were ranged between $\log { }^{10-7} 8.65-\log ^{10-7} 8.87$ and the highest total lactic acid bacteria was found in yoghurt with $0.2 \%$ modified starch added. It concluded in this research that the best quality of symbiotic yoghurt was in yoghurt with addition of modified starch of purple uwi bulb $0.3 \%$.

Keywords: Sinbiotic Yoghurt, Modified Starch of Ubi Purple Tuber, Sineresis, $\mathrm{pH}$ value, BAL Total

\section{PENDAHULUAN}

Air susu merupakan bahan pangan yang sangat dibutuhkan oleh manusia karena mengandung semua komponen bahan yang diperlukan dalam makanan manusia. Susu mengandung zat-zat gizi yang lengkap seperti protein, lemak, laktosa, air, mineral, vitamin dan lainlainnya.

Secara umum masyarakat telah banyak mengenal bermacam-macam susu yang telah diolah seperti : susu bubuk, susu UHT, susu kental manis, dan produk fermentasi dari susu yang lebih dikenal dengan yoghurt. Yoghurt adalah salah satu produk fermentasi susu yang menggunakan bakteri asam laktat yaitu Streptococcus thermophilus dan Lactobacillus bulgaricus dengan aroma khas dan rasa asam yang menyegarkan. Untuk meningkatkan kualitas dan nilai tambah yoghurt sebagai minuman kesehatan, perlu dilakukan penambahan bakteri probiotik pada yoghurt, dimana salah satu bakteri probiotik yang dapat digunakan yaitu Lactobacillus rhamnosus.

Probiotik didefinisikan oleh FAO dan WHO sebagai mikroorganisme hidup yang apabila dikonsumsi dalam jumlah yang cukup akan bermanfaat bagi kesehatan, mikroorganisme ini tidak bersifat toksik maupun patogen Probiotik digunakan untuk menyeimbangkan jumlah bakteri yang bermanfaat dan mengurangi jumlah bakteri yang merugikan yang terdapat dalam tubuh. Lactobacillus rhamnosus merupakan bakteri probiotik, yang mampu bertahan pada kondisi asam lambung, dapat meningkatkan fungsi pencernaan, serta dapat meningkatkan sistem kekebalan tubuh sehingga manfaat yoghurt sebagai minuman kesehatan menjadi lebih baik (Burton et al., 2014 ). Lactobacillus rhamnosus juga merupakan bakteri probiotik yang menghasilkan minuman fermentasi bermutu tinggi dengan total bakteri asam laktat yang dihasilkan sekitar 
$10^{8} \mathrm{CFU} / \mathrm{mL}$ pada es krim probiotik (Yelnetty, 2010).

Selain bakteri probiotik juga perlu ditambahkan prebiotik kedalam yoghurt yang dapat meningkatkan viabilitas bakteri probiotik yang digunakan. Prebiotik secara alami terdapat pada tanaman, misalnya pada umbi dahlia, bawang merah, bawang putih, asparagus, kedelai, ubi jalar. Prebiotik lain yang dapat digunakan adalah pati dari umbi uwi ungu (Dioscorea alata) yang termodifikasi menggunakan pendinginan dan proses pemanasan pada suhu $110^{\circ} \mathrm{C}$ dan $121^{\circ} \mathrm{C}$ selama 30 menit. Yoghurt dengan bakteri probiotik dan ingridient prebiotik disebut dengan yoghurt sinbiotik. Yoghurt sinbiotik merupakan yoghurt yang bersifat fungsional. Prebiotik dapat menjadi sumber energi atau nutrien terbatas lainnya bagi mukosa usus dan substrat untuk fermentasi bakteri dalam menghasilkan vitamin dan antioksidan yang dapat menguntungkan tubuh.

Umbi uwi ungu merupakan tanaman berumbi yang tergolong ke dalam familia Dioscoreaceae dari genus Dioscorea (Ayensu, 1972). Umbi dari jenis ini memiliki kandungan nutrisi yang tinggi dengan komposisi protein berkisar 7,4\%, pati $75-84 \%$, lemak, vitamin dan mineral kurang dari 4\% dalam $100 \mathrm{~g}$ berat kering umbi (Osagie, 1992; Hoover, 2001). Kandungan pati yang tinggi dari umbi uwi ungu dapat merupakan sumber serat pangan yang baik. Umbi uwi juga kaya akan kandungan inulin yang bersifat prebiotik, Pada umbi uwi kandungan inulinnya sekitar $5,12 \%$, dan penggunaan tepung umbi uwi $1,0 \%$ pada minuman fungsional biomilk menghasilkan kualitas terbaik dari segi fisik, kimia dan mikrobiologis pada minuman biomilk synbiotik yang dihasilkan. (Yelnetty dan Tamasoleng, 2019).

Berdasarkan penjelasan diatas maka telah dilakukan penelitian pembuatan yoghurt utnuk mengetahui kualitas fisikokimia dan mikorobia yoghurt sinbiotik yang diberi pati termodifikasi umbi uwi ungu (Dioscorea alata) dengan level berbeda.

\section{MATERI DAN METODE PENELITIAN}

Penelitian ini dilaksanakan di Laboratorium Jurusan Ilmu Produksi Ternak Fakultas Peternakan Universitas Sam Ratulangi Manado, pada tanggal 14 Desember 2018 sampai 8 Maret 2019. Bahan utama yang digunakan dalam penelitian ini adalah susu ultra high temperatur (UHT) sebanyak 5 Liter dan Skim $8 \%$, sukrosa $1 \%$, dan Starter yang digunakan adalah Streptococus thermophilus, Lactobacillus bulgaricus, Lactobacillus rhamnosus, yang diperoleh dari laboratorium Fakultas Peternakan 
Universitas Sam Ratulangi dan juga pati termodifikasi dari umbi uwi ungu (Dioscorea alata). Bahan - bahan lain yang digunakan untuk analisa adalah aquades, media Man Rogosa Shape medium (MRS), air tomat, agar, Calcium Carbonat $(\mathrm{CaCo} 3)$ dan spritus. Alat yang digunakan dalam penelitian ini adalah autoclave, incubator, erlenmeyer, tabung reaksi, $\mathrm{pH}$ meter, gelas ukur, gelas piala, cawan petri, thrmometer, timbangan analitik, thermolyne, alumunium foil, disposable, lemari pendingin, toples, pipet, oven, tissue, plastik, kater, karet.

Rancangan penelitian yang digunakan dalam penelitian ini adalah Rancangan Acak Lengkap (RAL) dengan 6 perlakuan dan 3 ulangan (Steel dan Torrie, 1991) Jika berbeda nyata maka akan lanjut menggunakan uji Beda Nyata jujur (BNJ). Sebagai perlakuan pada penelitian ini adalah penggunaan pati termodifikasi umbi uwi ungu (Dioscorea alata) terhadap kualitas Fisikokimia dan mikrobia yoghurt sinbiotik, sebagai berikut.

$\mathrm{P} 0=$ Tanpa penambahan pati termodifikasi $\mathrm{P} 1=$ Penambahan pati termodifikasi $0,1 \%$ $\mathrm{P} 2=$ Penambahan pati termodifikasi $0,2 \%$ P3 = Penambahan pati termodifikasi 0,3\% P4 = Penambahan pati termodifikasi 0,4\% P5 = Penambahan pati termodifikasi $0,5 \%$ Model rancangan percobaan adalah :

$$
\mathrm{Y}_{\mathrm{ij}}=\mu+\tau_{i}+\mathrm{E}_{\mathrm{ij}}
$$

$\mathrm{Y}_{\mathrm{ij}} \quad=$ Variabel yang akan dianalisi pada perlakuan ke-i ulangan ke-j

$\mu \quad=$ Rata-rata secara sebenarnya (nilai tengah populasi )

$\tau_{i} \quad=$ Pengaruh pada perlakuan ke-i

$\mathrm{E}_{\mathrm{ij}}=$ Galat eksperimen pada perlakuan ke-i ulangan ke-j

\section{Prosedur Kerja}

\section{Sterilisasi alat- alat}

Sterilisasi semua alat- alat yang akan digunakan (erlenmeyer, tabung reaksi, petridish, gelas ukur, gelas piala) dan alatalat yang digunakan lainnya. Sterilisasi dilakukan menggunakan Autoclaf pada suhu $121^{\circ} \mathrm{C}$ selama 20 menit.

\section{Pembuatan pati umbi uwi ungu (Dioscorea alata)}

Umbi uwi ungu (Dioscorea alata) dikupas dan dicuci bersih kemudian rendam dengan air selama 1 hari dan dilanjutkan dengan di parut, peras setelah itu didiamkan selama 20 menit di ambil endapannya (filtratnya), kemudian dipanaskan dengan suhu $70^{\circ} \mathrm{C}$ selama 15 menit setelah itu dikeringkan pada suhu $56^{\circ} \mathrm{C}$ selama 4 jam dan dilanjutkan dengan diblender dan terbentuklah pati umbi uwi ungu.

\section{Pembuatan Pati Termodifikasi Umbi uwi ungu (Dioscorea alata)}

Proses modifikasi pati alami dari umbi uwi ungu (Dioscorea alata) 
disuspensikan dengan cara menambahkan air dengan perbandingan pati dan air yaitu 1 : 3. Kemudian suspensi tersebut dipanaskan dalam autoclave pada suhu $110^{\circ} \mathrm{C}$ yang pertama kemudian di panaskan kembali pada suhu $121^{\circ} \mathrm{C}$ selama 30 menit. Setelah dipanaskan suspensi pati didinginkan pada suhu ruang selama 20 menit dan dilanjutkan dengan penyimpanan pada suhu $4^{\circ} \mathrm{C}$ selama 24 jam. Lalu dikeringkan pada suhu $60^{\circ} \mathrm{C}$ selama 24 jam dan setelah itu dihaluskan dengan cara diblender, pati yang telah dihaluskan diayak menggunakan ayakan 100 mesh. Setelah itu pati dikemas dengan menggunakan plastic dan ditutup rapat (Sajilata et al., 2006).

\section{Proses Pembuatan starter (Yelnety dan Tamasoleng, 2019)}

Membuat starter biakan bakteri Streptococcus thermophilus, Lactobacillus bulgaricus, Lactobacillus rhamnosus, dengan cara larutkan susu skim milk $8 \%$ dan Sukrosa 1\% dicampur dengan aquades kemudian disterilkan pada suhu $115^{\circ} \mathrm{C}$ selama 15 menit. Setelah itu didinginkan pada suhu ruang dan diinokulasikan dengan masing- masing bakteri Streptococcus thrmophilus, Lactobacillus bulgaricus, Lactobacilus rhamnosus dan kemudian diinkubasi dalam inkubator pada suhu $36^{\circ} \mathrm{C}$ selama 18jam.

\section{Proses Pembuatan Yogurt Sinbiotik (Rizqi et al., 2017)}

Susu ultra high temperature (UHT) dituangkan ke dalam wadah Masingmasing perlakuan menggunakan susu UHT sebanyak $200 \mathrm{~mL}$, dan untuk konsentrasi skim $8 \%$ ditimbang 16 gram untuk masingmasing perlakuan, dan sukrosa $1 \%$ ditimbang 2 gram, dan ditambahkan pati yang telah ditimbang untuk $200 \mathrm{~mL}$ masing-masing perlakuan, Lalu dihomogenisasi selama 5 menit kemudian dipasteurisasi pada suhu $80^{\circ} \mathrm{C}$ selama 15 menit setelah itu dilakukan pendinginan pada suhu $43^{\circ} \mathrm{C}$ selanjutnya diinokulasikan dengan menggunakan bakteri asam laktat (BAL) Streptococcus thermophilus, Lactobacillus bulgaricus, Lactobacillus rhamnosus sebesar 3\%, setelah itu diinkubasi dalam inkubator pada suhu $43^{\circ} \mathrm{C}$ selama 6 Jam.

\section{Prosedur Analisis}

Sineresis Yoghurt (Fadhila, 2013).

Sineresis adalah keluarnya air dari dalam gel, akibat adanya kontraksi di dalam massa gel.

Prosedur penentuan sineresis adalah sebagai berikut.

- Tabung sentrifuge dan sampel ditimbang.

- Dimasukkan ke dalam alat sentrifuge selama 10 menit dengan kecepatan 6 rpm. 
- Dipisahkan cairan dari endapan yoghurt, kemudian ditimbang endapan dalam tabung.

$$
\text { Rumus Sineresis }=\frac{A-B}{A} \text { X } 100 \%
$$

Keterangan:

$\mathrm{A}=$ berat awal sampel sebelum disentrifuge (gram)

B =berat akhir sampel setelah disentrifuge (gram)

\section{pH (Wahyudi, 2006)}

Mengukur nilai $\mathrm{pH}$ meggunakan elektroda $\mathrm{pH}$, alat $\mathrm{pH}$ meter dikalibrasikan dahulu dengan menggunakan larutan buffer sampai angka menunjukan $\mathrm{pH} 7$ lalu dikeringkan dengan tissue. Setelah angka pH stabil, diambil sampel kira- kira $50 \mathrm{ml}$ dan dimasukan ke dalam wadah kemudian elektroda $\mathrm{pH}$ meter dicelupkan ke dalam sampel dan segera dibaca $\mathrm{pH}$ meter pada skala meter.

\section{Total Bakteri Asam Laktat (Fardiaz, 1993)}

Menghitung total bakteri asam laktat dengan metode total plate count (TCP). Alat-alat yang digunakan disterilkan dalam autoclave pada suhu $121^{\circ} \mathrm{C}$ selama 30 menit, kemudian membuat larutan menggunakan aquades steril sebanyak 9 $\mathrm{mL}$ di setiap tabung reaksi sebanyak $10^{-1}$ sampai $10^{-7}$. Selanjutnya dilakukan dengan cara mempipet $1 \mathrm{~mL}$ larutan kedalam tabung reaksi yang berisi $9 \mathrm{~mL}$ larutan aquades sehingga diperoleh larutan $10^{-2}$, demikian seterusnya sehingga diperoleh pegenceran yang lebih tinggi. Dari masingmasing pengenceran $1 \mathrm{~mL}$ yaitu $10^{-2}$ dan $10^{-7}$ dimasukan ke dalam cawan petri kemudian media MRS dan juga agar, $\mathrm{CaCo} 3$ yang telah dibuat dan disterilkan yang telah didinginkan pada suhu $\left(45^{\circ} \mathrm{C}\right.$ $47^{\circ} \mathrm{C}$ ) dituangkan ke dalam cawan petri sebanyak $10 \mathrm{~mL}$ dan dibiarkan sampai beku. Cawan petri kemudian dibalik, dibungkus dengan plastik selanjutnya disimpan ke dalam inkubator dengan suhu $36^{\circ} \mathrm{C}$ selama 48 jam. Dari jumlah koloni yang diperoleh dikalikan dengan jumlah pengenceran, hasilnya merupakan jumlah total koloni bakteri.

\section{HASIL DAN PEMBAHASAN}

\section{Sineresis Yoghurt}

Rataan hasil sineresis dalam penelitian pada Tabel 1 untuk pengaruh penambahan pati termodifikasi dari umbi uwi ungu (Dioscorea alata) berkisar antara 18,67 sampai 22,67. Rataan sineresis yoghurt terendah diperoleh dari perlakuan P5 sebesar 18,67 sedangkan rataan sineresis yoghurt tertinggi diperoleh dari perlakuan P0 sebesar 22,67. 
Berdasarkan hasil analisis ragam menunjukkan bahwa pengaruh penambahan pati termodifikasi dari umbi uwi ungu (Dioscorea alata) memberikan pengaruh yang tidak berbeda nyata $(\mathrm{P}>0,05)$ terhadap sineresis yoghurt sinbiotik. Pada Tabel 1 diatas menunjukkan dengan penambahan pati termodifikasi $0,5 \%$ nilai sineresis yang di dapatkan sebesar 18,67. Dalam penelitian ini sineresis yoghurt memiliki kecenderungan dimana semakin tinggi konsentrasi pati termodifikasi umbi uwi ungu (Dioscorea alata) yang ditambahkan, maka semakin rendah sineresis Yoghurt. Hal ini sejalan dengan pendapat (Fadhila et al., 2013) menyatakan semakin tinggi konsentrasi penstabil pati yang ditambahkan, maka sineresis semakin rendah. Dengan semakin banyaknya pati termodifikasi umbi uwi ungu (Dioscorea alata) yang ditambahkan maka semakin tinggi pula nilai $\mathrm{pH}$ yang dicapai sehingga menimbulkan sineresis yang lebih rendah. Menurut (Saputro dan Winarti, 2013), umbi uwi ungu (Dioscorea alata) memiliki kandungan pati $86,12 \%$, amilosa 17,59\%, amilopektin 68,60\% termasuk kandungan yang tinggi dalam umbi uwi ungu (Dioscorea alata). Wilkinson (2000) menyatakan bahwa peningkatan kandungan pati pada susu dapat meningkatkan kekokohan gel dan viskositas serta menurunkan tingkat sineresis yoghurt.

\section{Nilai pH Yoghurt}

Rataan nilai $\mathrm{pH}$ dalam penelitian ini (Tabel 1) untuk pengaruh penambahan pati termodifikasi umbi uwi ungu (Dioscorea alata) berkisar antara 5,0 sampai 5,4. Rataan nilai $\mathrm{pH}$ terendah terlihat pada perlakuan P3 sebesar 5,0 sedangkan rataan nilai $\mathrm{pH}$ tertinggi diperoleh dari perlakuan P0, P4, dan P5 sebesar 5,4.

Tabel 1. Rataan Sineresis, nilai pH, dan Total Bakteri Asam Laktat

\begin{tabular}{ccccccc}
\hline \multirow{2}{*}{ Pengujian } & \multicolumn{5}{c}{ Perlakuan } \\
\cline { 2 - 7 } & P0 & P1 & P2 & P3 & P4 & P5 \\
\hline Sineresis & 22,67 & 22,00 & 21,33 & 20,00 & 19,00 & 18,67 \\
Nilai pH & $5,40^{\text {a }}$ & $5,30^{\text {a }}$ & $5,23^{\mathrm{b}}$ & $5,07^{\mathrm{c}}$ & $5,40^{\text {a }}$ & $5,40^{\text {a }}$ \\
Total BAL & $7,5332^{\mathrm{b}}$ & $8,6478^{\text {a }}$ & $8,8671^{\text {a }}$ & $8,8289^{\text {a }}$ & $8,7384^{\text {a }}$ & $8,7653^{\text {a }}$
\end{tabular}

Keterangan : Superskrip yang berbeda pada baris yang sama berbeda sangat nyata $(\mathrm{P}<0,01)$ 
Berdasarkan hasil analisis keragaman menunjukkan bahwa penambahan pati memberikan pengaruh yang sangat nyata $(\mathrm{P}<0,01)$ terhadap nilai pH yoghurt. Pada perlakuan P3 $(0,3 \%)$ menunjukkan nilai $\mathrm{pH}$ mengalami penurunan, namun ketika ditambahkan pati termodifikasi pada perlakuan P4 sebesar $(0,4 \%)$ dan P5 (0,5\%) mengalami peningkatan nilai $\mathrm{pH}$. Hasil uji BNJ menunjukkan bahwa nilai $\mathrm{pH}$ yoghurt dengan penambahan Pati termodifikasi umbi uwi ungu (Dioscorea alata) dengan perlakuan Kontrol (P0) berbeda sangat nyata $(\mathrm{P}<0,01)$ dibandingkan dengan perlakuan P2 $(0,2 \%)$ dan P3 $(0,3 \%)$ Tetapi tidak berbeda nyata $(\mathrm{P}>0,01)$ dibandingkan dengan perlakuan P1 $(0,1 \%), \mathrm{P} 4(0,4 \%)$ dan, P5 (0,5\%). Hal ini dapat di lihat pada Tabel 1, yang menunjukkan bahwa semakin banyak pati termodifikasi umbi uwi ungu (Dioscorea alata) nilai $\mathrm{pH}$ yang di dapatkan bertambah tinggi. Penurunan $\mathrm{pH}$ terjadi pada penggunaan Pati umbi uwi ungu (Dioscorea alata) pada perlakuan (P3) sebanyak 0,3\%, setelah itu dengan penambahan pati terjadi kenaikan nilai $\mathrm{pH}$. Lebih tingginya nilai $\mathrm{pH}$ dikarenakan dalam pemberian pati di setiap perlakuan hanya $0,1 \%$ sampai $0,5 \%$ dan di dalam pati tersebut memiliki kandungan karbohidrat pada tanaman tingkat tinggi yang mengandung dua komponen utama yaitu amilosa dan amilopektin. Hal ini disebabkan karena penambahan Pati termodifikasi umbi uwi ungu (Dioscorea alata) dengan konsentrasi yang tinggi menyebabkan kadar asam yang dihasilkan dinetralkan oleh Pati umbi uwi ungu (Dioscorea alata). Hal ini sejalan dengan pendapat (Wakhidah et al., 2017) Semakin banyak formulasi pati yang digunakan makin rendah nilai $\mathrm{pH}$ yoghurt sinbiotik. Pada Tabel 1 diatas menunjukkan bahwa hanya dengan pemberian pati $0,1 \%$ sampai 0,5\% sehingga nilai $\mathrm{pH}$ pada Tabel 1 lebih tinggi jika dibandingkan dengan standart mutu yogurt. nilai $\mathrm{pH}$ yang didapatkan masih termasuk baik untuk minuman fermentasi (Yelnetty dan Tamasoleng, 2019).

\section{Total Bakteri Asam Laktat}

Rataan total bakteri asam laktat pada penelitian ini Tabel 1 menunjukkan untuk pengaruh penambahan pati termodifikasi umbi uwi ungu (Dioscorea alata) berkisar antara 7,5332 sampai 8,8671 (Log cfu/mL). Rataan total bakteri asam laktat terendah diperoleh dari perlakuan P0 (kontrol) sebesar 7,5332 sedangkan rataan total bakteri asam laktat tertinggi diperoleh dari perlakuan P2 sebesar 8,8671.

Berdasrkan hasil analisis ragam menunjukkan bahwa pengaruh penambahan pati termodifikasi umbi uwi ungu (Dioscorea alata) memberikan 
pengaruh yang berbeda sangat nyata $(\mathrm{P}<0,01)$ terhadap total bakteri asam laktat.

Hasil Uji BNJ menunjukkan bahwa bakteri asam laktat dengan penambahan pati termodifikasi umbi uwi ungu (Dioscorea alata) dengan perlakuan P2 $(0,2 \%)$ berbeda sangat nyata $(\mathrm{P}<0,01)$ dibandingkan dengan perlakuan P0 (kontrol), tetapi tidak berbeda nyata $(\mathrm{P}>0,01)$ dibandingkan dengan perlakuan P3 $(0,3 \%)$, perlakuan P5 (0,5\%), perlakuan P4 $(0,4 \%)$, dan perlakuan $\mathrm{P} 1(0,1 \%)$. Pada Tabel 1 dapat diketahui bahwa semakin tinggi kadar pati termodifikasi yang di tambahkan maka semakin besar total bakteri asam laktat (BAL) yang di hasilkan. Hal ini menunjukan bahwa penggunaan pati umbi uwi ungu (Dioscorea alata) sebagai kandungan nutrisi yang cukup baik bagi pertumbuhan bakteri asam laktat, kandungan protein $7,4 \%$, pati $75-84 \%$ dan lemak, vitamin dan mineral kurang dari $4 \%$ dalam $100 \mathrm{~g}$ berat kering (Saputro dan Winarti. 2013). Ini sesuai dengan pendapat (Muhamad et al., 2014) bahwa dalam pati merupakan bagian yang dominan dari kandungan karbohidrat yaitu berkisar $85,20 \%$ sebgai sumber karbon yang di manfaatkan oleh bakteri asam laktat sehingga berdampak pada menigkatnya total bakteri asam laktat (BAL).

\section{KESIMPULAN}

Berdasarkan hasil analisa data dan pembahasan untuk semua variabel pada penelitian ini maka dapat disimpulkan bahwa kualitas terbaik yoghurt sinbiotik adalah pada yoghurt dengan penambahan pati termodifikasi umbi uwi ungu sebesar $0,3 \%$.

\section{DAFTAR PUSTAKA}

Ayensu, E.S. dan D.G. Coursey. 1972. Guinea yams. The botany, ethnobotany, use and possible future of yams in West Africa. Econ. Bot. 26: 301-3 18.

Burton, E., I.I. Arief, E. Taufik. 2014. Formulasi yoghurt probiotik karbonasi dan potensi sifat fungsionalnya. Jurnal Ilmu Produksi dan Teknologi Hasil Peternakan 2(1): 213-218

Fadhila, A. P. P., R. Rusdin, E. Purwani. 2013. Sifat Kimia dan sineresi yoghurt yang dibuat dari tepung kedelai full fat dan non fat dengan menggunakan pati sagu sebagai penstabil. Jurnal Ilmu Kesehatan 6(2): $145-152$

Faridiaz, S . 1993. Analisis Mikrobiologi Pangan. Raja Grafindo Persada, Jakarta.

Muhamad, N. A., H. Yusuf, Y. Rini. 2014. Analisis sifat fisik dan kimia pada pembuatan tepung umbi uwi ungu (Discorea alata), uwi kuning (Discorea alata) dan uwi putih (Discorea alata). Jurnal Keteknikan Pertanian Tropis dan Biosistem 2(3): 297-303. 
Nur, W., J.M. Godras, U. Rohula. 2017. Yoghurt susu sapi segar dengan penambahan ekstrak ampas jahe dari destilasi minyak atsiri. Jurnal. Konferensi Pendidikan Prosiding Biologi 14(1): 278-284

Rizqi, Z. I., C. Dewi, N.H. Mustika, H. Sri. 2017. Penetuan umur simpan yoghurt sinbiotik dengan penambahan tepung gembolomodifikasi fisik. Jurnal. Teknologi Agroindustri 2(1): 1-6.

Sajilata, M.G., R.S. Singhal, P.R. Kulkarni. 2006. Resistant starch a review. Comprehensive Reviews in Food Science and Food Safety. 5(1): 1-17. https://doi.org/10.1111/j.1541433 7.2006.tb00076.x

Saputro, E. A. dan S. Winarti. 2013. Karakteristik tepung prebiotik umbi uwi (Dioscorea spp). Jurnal Teknik Kimia 8(1): 18-19.

Standar Nasional Indonesia (SNI). 2009. SNI 2981:2009. Yogurt. Badan Standarisasi Nasional (BSN), Jakarta.

Steel, R.G.D dan J.H. Torrie. 1991. Prinsip dan Prosedur Statistika. Gramedia Pustaka Utama, Jakarta.

Wahyudi, M. 2006. Proses pembuatan dan analisis mutu yoghurt. Buletin Teknik Pertanian 11(1): 12 - 16.

Wilkinson, M. 2000. Improving the Quality of Yogurt. www.teagascie/research/reports/dai ryproduction/4615/eopr4615.htm22k. Diakses tanggal 28 September 2013.

Yelnetty, A., M. Tamasoleng, R. Hadju. 2018. Potensi Biomilk Synbiotik Menggunakan Probiotik L. rhamnosus dan Prebiotik Lokal Umbi Uwi (Dioscorea alata) Sebagai Pangan Fungsional Dalam
Mencegah Obesitas. Unpublished. Laporan Penelitian Riset Terapan Unggulan Unsrat.

Yelnetty, A. 2010. Kualitas Es Krim Probiotik Dari Ubi Jalar (Ipomea batatas,L) Menggunakan Streptococcus Thermophillus, Lactobacillus acidophilus, Lactobacillus rhamnosus dan Bifidobacterium logum. Jurnal Sains 10(1): 20-27.

Yelnetty, A. dan M. Tamasoleng. 2019. The addition of Yam Tuber (Dioscorea alata) flour as a source of prebiotic on biomilk synbiotic characteristics. Journal IOP Conference Series: Earth and Environmental Science 247(1): 012-052. 